\title{
Knecht Tamás „A szók alakításáról” című Brassai-kézirathoz
}

I. Az 1950-es években rendeletileg megszüntetett kolozsvári unitárius főgimnázium könyv- és kézirattára is a Román Akadémia Kolozsvári Fiókjának őrzésébe került. Ez utóbbi intézmény kutatóinak egyike, dr. Lakó Elemér 1980-ban fejezte be Catalogul manuscriselor unitariene păstrate la Biblioteca Filialei Cluj-Napoca a Academiei R.S.R. (Az Unitárius Kollégium könyvtára kéziratainak katalógusa) Vol. I (Cluj-Napoca, 1980) címü munkáját, amely a Szegedi Tudományegyetem régi magyar tanszéke gondozásában angolul jelent meg 1997-ben. $\mathrm{Ez}$ a nevezett intézményben őrzött unitárius kézirattári anyag teljes értékű és átfogó katalógusa, amelyben a Brassaihoz kapcsolható tételek között egy szerzői kéziratban ránk maradt magyar nyelvü latin grammatika-töredék is szerepel.

Mivel azonban a Brassai nyelvtudományi munkásságával foglalkozó szakirodalom ezt a munkát - úgy tünik - nem ismeri, a továbbiakban a Lakó-féle, természetszerüleg szűkszavú ismertetést igyekszem kiegészíteni. Majd pedig e Brassai-mü magyar nyelvtudományi terminológia-történeti vonatkozásaira és az ezekkel összefüggő leíró nyelvészeti vonatkozásokra térek ki. ${ }^{136}$

\section{A kézirat ismertetése:}

1. Alaki leírás: a kézirat jelzete a fent említett örzési helyen: Ms. U 1521. A kézirat kék fedőlapja néhány korábbi jelzettől eltekintve üres. Huszonöt fólióból áll, a 35. lap verzója és a 47. rektója beíratlan. A félfóliók számozását piros színű ceruzával később jegyezték be. A szerző által használt tinta szinte fekete. A félfóliók mérete, miként azt már Lakó Elemér megállapította, $198 \times 125 \mathrm{~mm}$. Az írástükrök nagysága változó. A sorok száma a teleírt lapokon 21 és 30 között ingadozik. A teljes szöveg egyetlen kéz munkája. Hogy ez a kéz Brassai keze, arról magam is meggyőződhettem, mivel egybevetettem az Ms.U. 690 jelzetü Metaphysika, illetve az Ms.U. 12588 jelzetü Szanszkrit jegyzetek II. címü kéziratokkal, amelyek kétségbevonhatatlanul Brassai munkái.

\section{A kézirattal kapcsolatos feltételezések:}

Szinte bárki által könnyen felismerhető, hogy a kézirat egy latin grammatika töredéke. Boros György monográfiája Brassai tankönyveivel kapcsolatosan megemlíti, hogy írt egy kétkötetes latin nyelvtant, mely 1842-ben már készen is állt, de a kedvező bírálat ellenére sem jelent meg. ${ }^{137}$ A későbbiekben talán éppen ezért veszhetett nyoma a kéziratnak.

Fitz József Brassai-monográfiájában azt olvassuk, hogy Brassainak „a unit. Főgimnázium könyvtárában van egy latin nyelvtan töredéke: A' szók alakításáról."138 Mindezek alapján indokolt föltételeznünk, hogy az általunk vizsgált kézirat és a Fitz említette töredék azonos, és hogy ez a latin grammatika-töredék nem azonos az 1872-ben Kolozsváron megjelent Hogyan kelljen a latin hajtogatást ésszerüen, gyorsan és sikeresen tanitani címü Brassai-munkával. Ez utóbbi ti. A conjugatiokkal kapcsolatos gyakorlatokat kérdések formájában tartalmazó tanári segédkönyv.

\footnotetext{
${ }^{136}$ Itt is köszönöm Lőrinczi Rékának, hogy felhívta figyelmemet a LAKÓ-katalógusra és erre a kéziratra.

137 Boros György, Dr. Brassai Sámuel élete. Minverva Irodalmi és Nyomdai Műintézet Részvénytársaság. Kolozsvár, 1927:137 1.

${ }^{138}$ Fitz József, Brassai Sámuel. Monográfia. Bp., 1912:76.
} 


\section{A kézirat tartalmának ismertetése:}

Ez a ránk maradt grammatika-töredék két egységre oszlik. Az elsőben Brassai a latin szóalkotási módok közül kettőt mutat be: a szóképzést és a szóösszetételt. A második részt (mai terminussal) szófajtaként határozhatnók meg.

A kézirat a szóképzés bemutatásával kezdődik. 1r: „a’ törzsök szókból előragok és utóragok és némi változtatások által származott szók alakíttatnak.” Utóragoknak azokat a „,végzeteket” nevezi, melyeket: 1r: „a' szó törzsökéhez szokták ragasztani”, míg 20r: „előragok azok, melyek a' törzsöknek elébe tétetnek".

A munka az „utóragok” felsorolásával folytatódik. Brassai elmondja, hogy ezekkel verbumokat, substantivumokat, adjectivumokat, adverbiumokat, számneveket (sic!) és pronomeneket képezhetünk. Megemlítendő, hogy a szerző a beszédrészeket hol latinul, hol magyarul említi. Kivétel csupán a számnév, melyet mindig magyar elnevezéssel emleget.

Az „elöragok” csoportjának leírását sajátosságaik bemutatásával indítja, majd felsorolja őket. Külön megtanulandó cím alatt azonban a kivételeket is számba veszi. A szóösszetételeket tárgyalva a verbumok, substantivumok, adjectivumok pronomenek, adverbiumok, valamint conjunctiok más szavakkal való „összeragasztásá”-ról ír.

A szóalkotást követő, tehát a második rész címe: a Beszéd részei (partes orationis). A szófajfelosztás a szavak mondatban betöltött szerepe alapján történik.

Megtudjuk, hogy a nomenek substantivumokra és adjectivumokra tagolódnak. A pronomeneket aszerint, hogy: 46v: „magukban is megérthető" vagy pedig csak: 46v: „substantivum mellett állnak” pronomina substantiva-nak, illetve adjectiva-nak nevezi.

A verbumokat ,jelentésük szerint” és ,a conjugatio formájára nézve” különíti el.

A szófajtan a továbbiakban az adverbiumok, a praeposotiok, a conjunctiok és az interjectiok funkciójának bemutatásáig jut el, majd a következő mondattal zárul: 5r: „Analysis v. Resolutio grammatica, midőn a' tanuló a' latin könyvekben előforduló minden szókat, a' felebbi számok szerint megnevezni tud".

III. A kéziratban használt nyelvtudományi terminusok kérdései:

Elörebocsátandó, hogy Brassai ebben a müben a latin terminusoknak csak egy részét helyettesítette magyar megfelelővel. Ennek oka az lehet, hogy latin nyelvről szóló grammatikát írt, ezért hagyhatta meg az évszázadok során már állandósult és egyetemes használatú latin terminológiát. A magyar szakszavak használatát Brassai idejében is még nagyfokú állandósulatlanság, vagyis ugyanaz jellemezte, amit az 1795-ben megjelent Debreceni Grammatika előszava nem ok nélkül így fogalmazott meg: „... (Mester-Szók) Magyarul kitéve, ... eleinte bajt és homályt okoztak."139

A most vizsgált Brassai-kéziratban használt terminusok közül változatlan jelentéssel az alábbiak azóta is használatosak: idő, ige, indulatszó, mód, nem, névmás, óhajtó igék, szám, számnév, személy, szenvedő ('szenvedô ige'), végzödés.

A terminusok másik csoportjának megértéséhez viszont ma már szükséges a jelentés meghatározása is: arányos szám 'numeralia proportionália', beszédrész ; 'szófaj', bírást jelentő szó 'birtoklást jelentő, azaz birtokszó', birtoklók 'birtokos névmások', egyszerürag 'egy hangból álló toldalék', elörag 'praefixum', elöszó 'praepositio', ismétlö ige 'gyakorító ige', ismétlő 'ismétlődő névmások', kezdő igék 'verba inchoativa', kicsinyitő rag 'kicsinyítő jelentésü toldalék', kötszó 'kötőszó', középigék 'verba neutra', mondás 'mondat' (1. Alább

\footnotetext{
${ }^{139}$ Magyar Grammatika, mellyet készített Debreczenben egy Magyar Társaság. Bétsbenn, 1795: XXVII. 1
} 
részletezve!), mutatók 'mutató névmások', névhelyettes 'névmás', öszve illesztô számok 'osztószámnevek', rag 'toldalék', rendező számok 'sorszámnevek', származott szók 'származékszók', szorzatos szám 'szorzószámnév', törzsök 'tő', (mely lehet: hosszú v. kurta; egész, csonkitott v. toldott; elváltozó), törzsökszók 'tőszók', utórag 'szuffixum', vegyesek 'vegyes névmások, azaz határozatlan névmások', végbetü 'szóalakzáró hang', végzet 'végződés'. A Brassai által használt fenti terminusok közös sajátsága az egyjelentésüség. A névhelyettes és a névmás, illetve a végzet és a végződés müszók szinonímái egymásnak.

A Brassai-féle terminusokat egybevetettem a legfontosabb kortárs grammatikák müszójegyzékeivel, vagyis az illető mü által használt nyelvtani szakkifejezések ,értelmező szótáraival”. Ezek a grammatikák a következök: Földi János, Magyar Nyelvkönyv avagy Grammatika (1790), Gyarmathi Sámuel, Okoskodva tanitó magyar nyelvmester (1794), Debr.Gr., Verseghy Ferenc, Magyar Grammatika avagy Nyelvtudomány (1818, 1821). A conjugatio, interjectio, praepositio, valamint a pronomen terminusok magyar megfelelöinek az összehasonlítását Zsinka István, a beszédrészek magyar elnevezéseinek története (Bp., 1939.) címü munkájának segítségével végeztem el.

Az egybevetés során kitetszett, hogy bizonyos müszavak csupán Brassai munkájában fordulnak elő. A Brassai újításának tünő terminusok javarészt tisztán alaktani müszavak: elörag, utórag, egyszerürag. ${ }^{140}$ Szófajtani kategóriát megnevező pedig a névhelyettes. Ide sorolhatók a szófaji alkategóriát megnevező müszavak is: rendezö, szorzatos, arányos, illetve öszve illesztö számok, ismétlö, illetve vegyes névmás vagy névhelyettes, valamint az ismétlö ige. Az elö- és utórag müszavakat a latin praefixum és suffixum magyar megfelelöiként használja a szerző. Az egyszerürag terminus egy hangból álló toldalékot jelent.

A szerző által használt névhelyettes szinonímáiként az említett szerzőknél a következő terminusok szerepelnek: névváltó, névpótló, illetve a névmás birtokjeles (névmássa) vagy birtokjel nélküli alakjai. Brassai rendező szám terminusa fölöttébb hasonlít a DebrGr. (236) és Gyarmathi (XXVIII) rendelö szám, illetőleg Verseghy (XXXV) rendszám terminusaira. A Brassai használta ismétlő igének Verseghy grammatikájában a többszöröző ige felel meg. Az ismétlö, illetve vegyes névmás ugyanebben a müben visszatérö, illetőleg határtalan névpótoló-ként jelenik meg.

A kevésbé közismert további grammatikákkal való összevetés még hátra van. Így mostani megállapításaim csupán hipotézisnek tekinthetők.

IV. Befejezésként a fentebb említett mondás-sal kapcsolatban szeretnék észrevételeket tenni. A kézirat e terminusának - mint ahogy azt előbb már jeleztem - a mondat müszó felel meg. Ez a terminus a maga korában feltehetőleg egyáltalán nem hatott szokatlanul. Több grammatikában - pl. Verseghynél (XXXIV. 1.) és a DebrGr.-ban (235 1.) is előfordul.

Brassainál nem is magának a terminusnak a használata figyelemre méltó, hanem az, amit mondás-on 'mondaton' ért. Ehhez hasznos lehet idéznünk azt, amit a kéziratban az interjectio meghatározásában olvashatunk: 50v: „Interjectiok v. indulatszók az indulat felkiáltásai, 's magukra mondást képeznek”. Innen szeretném kiemelni a „magukra mondást képeznek” részt. Ezt ti. bizonyára úgy kell értenünk, hogy magukban önálló mondatok. Ezáltal viszont Brassai a most ismertetett kézirat keletkezésekor, azaz már 1840 körül mint funcionális egységet tárgyalja a mondatot, elődeivel/kortársaival és számos utódjával ellentétben, akik a mondatot még - mai terminussal élve - szerkezeti egységnek tekintették.

\footnotetext{
${ }^{140}$ Ezekhez is 1. T. Somogyi Magda, Toldalékaink (rendszerezéstörténet és összehasonlítás) Újabb fejezetek a magyar leíró nyelvtan köréből. Szerk. Keszler Borbála. Kézirat. Tankönyvkiadó. Bp, 1993: 225-32.
} 